\title{
МОВНА КОМПЕТЕНЦІЯ ЯК СКЛАДНИК КОМУНІКАТИВНОЇ ПРОФЕСІОГРАМИ ПУБЛІЧНОГО УПРАВЛІНЦЯ
}

У статті розглядаються питання мовної підготовки публічних управлінців у рамках професіоналізації державної служби, визначаються шляхи зростання мовної компетенції працівників иієї сфери.

Відповідно до реалізації мети, яка полягає в окресленні шляхів оволодіння публічними управліниями мовною компетенцією, узагальнено низку завдань, пов 'язаних із підходами до ключових понять, визначено мовну компетенцію як фактор формування професійного іміджу управлінців, розроблено пропозицї для вдосконалення мовної підготовки, запропоновано засоби поглиблення мовної компетенції через систематизовану мовнокомунікативну професіограму.

Ключові слова: професійна компетенція, комунікативна компетенція, мовна компетенція, комунікативна професіограма, форми піднесення комунікативної культури.

Zahrebelna L.S. Linguist Competence As a Component of the Communicative Professiogram of Public Servants. At the present stage of the state-building in Ukraine, professionalisation of the public service and formation of the professional linguistic competence of public servants are top-priority issues. Proper command of the state language and the ability to use it correctly is mandatory for the people working in public administration. In this regard, an urgent need arises to clearly identify the competences of business communication and the areas of competence development of public servants generating strong interest on behalf of scientists. The rationale of the topic researched is determined by both the theoretical and practical importance of the issues related to the improvement of the professional speech of specialists working under conditions of constant communication (contact and distant, direct and indirect, oral and written, dialogic and monologic, interpersonal and mass, private and official, informational and factual, related to the inner world of the speaker).

The objective of the research is to determine the ways of improving the linguistic competence of public servants. tasks:

The achievement of the objective in question provides for implementation of the following

- Generalise the approaches to the definitions of the notions of "communicative competence," "linguistic competence," "communicative behaviour," "culture of business communication," and "communicative professiogram"

- Determine the linguistic competence as a factor required for shaping up the professional image of a public servant

- Develop proposals for enhancing the linguistic training of public servants

- Propose the measures to deepen the linguistic competence of public servants through the systematised linguistic communicative professiogram

The article presents a set of measures aimed at improving the linguistic competence of public administration employees. The emphasis is made on the communicative professiogram which outlines the components of linguistic competences required and the forms of enhancing the communicative culture of public servants.

Key words: professional competence, communicative competence, linguistic competence, communicative professiogram, forms of enhancing the communicative culture. 


\section{Вступ}

Нині розвиток України позначений пильною увагою до проблем, пов'язаних із державною мовою та мовною політикою. В енциклопедичному виданні «Українська мова» зазначено, що державна мова - це «закріплена традицією або законодавством мова, уживання якої обов’язкове в органах державного управління та діловодства, громадських органах та організаціях, на підприємствах, у державних закладах освіти, науки, культури, у сферах зв'язку та інформатики» (Українська мова: енциклопедія, 2013: 126). Тому сучасний фахівець повинен усвідомлювати, що в демократичній країні кожен має не лише право на плекання рідної мови, але й обов'язок утверджувати ії щоденно. Для цього необхідно вправно володіти літературною мовою, добре орієнтуватися в усіх іiї нормах, застосовувати в практичній діяльності набуті знання, уміння й навики. Це нагальна вимога сьогодення, свідчення кваліфікаційного й інтелектуального рівня людини. Кожен мусить зрозуміти, що бездоганне володіння українською мовою у своїй практичній діяльності є невід'ємним складником поваги до власного народу, іміджевим показником і запорукою особистого кар'єрного зростання.

Людина існує в умовах постійного спілкування - контактного і дистантного, безпосереднього й опосередкованого, усного й писемного, діалогічного й монологічного, міжособистісного й масового, приватного й офіційного, інформаційного й фатичного (пов'язаного з внутрішнім світом мовця). Через це й постає необхідність набуття мовної компетенції, розвитку певних комунікативних навиків, які б відповідали загальним етичним вимогам та етикетним нормам українського суспільства. Те, що культура спілкування $€$ надзвичайно важливим елементом, не викликає заперечень, бо поза нею відбувається руйнація взаємодії людей, їх виробничої діяльності, а також побуту. Під культурою ділового спілкування у сфері публічного управління слід розуміти дотримання особою вимог до усного й писемного мовлення в реалізації нею своїх офіційно-ділових обов'язків. Серед параметрів, за якими визначається рівень сформованості культури мовлення загалом і ділового мовлення окремої особи, виділяються такі, як правильність, чистота, точність, логічність, дохідливість (Редін, 2016: 29).

Володіння культурою ділової комунікації допомагає уникнути непорозуміння між співробітниками, налагодити довірливі стосунки з громадянами, попередити конфліктні ситуації, забезпечити ефективну роботу. Оскільки специфіка діяльності публічних управлінців передбачає обгрунтування цілей і напрямів суспільного розвитку, володіння особливим предметом праці - інформацією, яка виступає засобом публічного нагляду й надання адміністративних послуг, необхідною є цілеспрямована робота над удосконаленням професійних навиків ділового спілкування, засвоєнням механізмів власної психології, мовнокомунікативної компетенції.

У зв'язку із цим виникла нагальна потреба в розвитку компетентності й визначенні компетенцій ділового спілкування публічних управлінців, що викликає неабиякий інтерес науковців. Увага дослідників фокусується на проблемах нормативності української ділової мови, на культурі мови та 
мовлення, про що свідчать напрацювання С. Дорошенко, Р. Кацавця, О. Козієвської, І. Лопушинського, І. Злотницької, П. Редіна, Ж. Соколовської, В. Терещенка; на питаннях сучасної теорії і практики мовної комунікації та ділового спілкування (Ф. Бацевич, В. Гошовська, Л. Загребельна, О. Левченко); на аспектах мови професійного спрямування та питаннях формування мовної компетенції фахівців (І. Клименко, Л. Кулакевич, М. Пентилюк, С. Шевчук). Значну роль відіграють праці науковців про риторику в публічному управлінні (Г. Гамова, Л. Ткаченко, С. Хаджирадєва).

Актуальність пропонованої теми пов'язана з пошуками шляхів розвитку мовної компетенції публічних управлінців.

Мета дослідження полягає у визначенні напрямів вироблення мовної компетенції фахівців сфери державного управління.

Реалізація поставленої мети передбачає вирішення таких завдань:

- узагальнити підходи до визначення змісту понять «комунікативна компетенція», «мовна компетенція», «комунікативна поведінка», «культура ділової комунікації», «комунікативна професіограма»;

- визначити мовну компетенцію як фактор формування професійного іміджу публічного управлінця;

- розробити пропозиції для вдосконалення мовної підготовки публічних управлінців;

- запропонувати засоби поглиблення мовної компетенції управлінців через систематизовану мовнокомунікативну професіограму.

\section{Методи та методики дослідження}

Для досягнення мети й реалізації поставлених завдань були використані такі методи: системно-структурний, порівняння та узагальнення, вивчення досвіду роботи, виявлення критеріїв відбору щодо змісту мовнокомунікативної підготовки публічних управлінців.

\section{Результати та дискусії}

Суспільство й держава потребують належного кадрового забезпечення висококваліфікованими й компетентними фахівцями, здатними ефективно працювати в органах державної влади та місцевого самоврядування. Це насамперед стосується питання володіння культурою ділової комунікації працівниками публічної сфери.

Уміння правильно й переконливо спілкуватися, логічно висловлювати свої думки є особливо важливими для працівників сфери публічного управління, людей, які працюють у державному секторі, створюють його імідж, регулюють правові взаємовідносини між державою й громадянами. Ці працівники постійно звертаються до ділового мовлення, проводячи наради чи спілкуючись телефоном, здійснюючи особистий прийом громадян чи виступаючи з промовами. Тож здійснювана ними ділова комунікація свідчитиме про кваліфікаційний та інтелектуальний рівень фахівців, а також їхньою компетенцію. Поняття «компетенція» взаємопов'язане з поняттям «кваліфікація». Виникнення поняття компетенції вписується в історію професійної підготовки. Швидкі зміни багатьох професійних завдань (зокрема 
управлінських) вимагають високого рівня кваліфікації. Для вирішення професійних завдань, окрім загальних компетенцій, спільним є володіння мовними компетенціями. Управлінцеві треба вміти передбачати труднощі, приймати рішення, співпрацювати, а також координувати свою діяльність. Усе це неможливо реалізувати, не володіючи переконливим, логічним, точним словом. Від цього залежить успіх діяльності фахівця. Міркування щодо компетенції і кваліфікації проектуються на професійні компетенції, до яких найперше належать мовна й комунікативна компетенції.

Мовна компетенція - це знання учасниками комунікацій мови (мовного коду), тобто правил, за якими формулюються правильні мовні конструкції та повідомлення, здійснюється їх трансформація. Вона передбачає володіння засобами мови, знання законів їх використання на фонологічному, семантичному і структурно-синтаксичному рівнях для творення потрібних дискурсів і текстів. Щодо комунікативної компетенції, то це сукупність знань про спілкування в різноманітних умовах і з різними комунікантами, а також знань вербальних і невербальних засад інтеракцій, умінь їх ефективного застосування у конкретному випадку в ролі адресата й адресанта (Бацевич, 2004: 123-124). I мовну, і комунікативну компетенції людина вдосконалює все своє життя в різних ситуаціях, тому їх формування є основною метою мовного навчання фахівців різних галузей.

Мовнокомунікативна компетенція публічного управлінця є важливим питанням, яке належить до головних професійних характеристик і містить такі основні складники:

- знання основ культури української мови (мова й культура мовлення в житті професійного комунікатора; комунікативні ознаки культури мовлення; мовний етикет);

- розуміння особливостей професійної комунікації та опанування майстерністю ділового спілкування у сферах пізнавально-трудової і творчої діяльності;

- оволодіння культурою усного й писемного фахового спілкування (індивідуальні й колективні форми обговорення професійних проблем; робота з документами);

- удосконалення майстерності публічного виступу.

Через це вдосконалення професійномовленнєвої комунікації управлінців вимагає навчання впродовж усього життя, при цьому треба підвищувати вимоги до комунікативної практики управлінців, оскільки рівень їх професійнокомунікативної діяльності значною мірою впливає на вирішення стратегічних питань, на контакт зі споживачами управлінських послуг. Тому вкрай необхідною є якнайповніша реалізація особистісного мовленнєвого потенціалу кожного працівника щодо власного соціально-комунікативного зростання, бо сучасна освічена людина повинна прагнути довершеності в культурі спілкування й комунікації.

Відомо, що спілкування відбувається за визначеними правилами і вимагає серйозної, грунтовної підготовки. Спілкування іноді ототожнюють із комунікацією, та це не синоніми, бо комунікація є цілеспрямованим 
інформаційним обміном у різноманітних процесах спілкування (Шевчук, 2013: 150). Комунікативна ж компетенція фахівця є важливим питанням, яке потребує вивчення шляхів ії̈ зростання.

Серед кваліфікаційних і моральних вимог до управлінців виділяють 3-поміж інших найперше такі, як досконале володіння державною мовою, стилістикою офіційних документів і правилами діловодства.

Якщо комунікативна компетенція належить до ключових професійних характеристик, то необхідно укласти комунікативну професіограму управлінця, яка визначатиме основні складові необхідних компетенцій і вказуватиме на шляхи здобуття таких умінь, як:

- формування мети й завдань професійного спілкування;

- керування спілкуванням із чіткою його регламентацією;

- використання етикетних засобів для досягнення комунікативної мети;

- володіння стилістичною вправністю;

- уміння укладати ділові документи різних груп і видів та ін.

Цей перелік професійних навиків є частковим.

Для досягнення належного рівня професійної компетенції управлінців необхідно дбати про систематичне піднесення їх комунікативної культури й мовленнєвої компетенції в таких формах, як:

- організація навчання за професійними програмами з питань підвищення кваліфікації для короткотермінових і довготривалих курсів при вищих навчальних закладах, а також на замовлення органів влади, організацій, підприємств, установ;

- запровадження постійно діючих тематичних семінарів;

- проведення навчання працівників органів державної влади та місцевого самоврядування на рівні міста, району, області, а також на робочих місцях із залученням фахівців із питань комунікативної та діловодної культури у формі лекцій, практичних занять, семінарів, семінарів-тренінгів, інтенсивних семінарів, вебінарів та ін.;

- проходження стажування в Інституті підвищення кваліфікації керівних кадрів Національної академії державного управління при Президентові України та в регіональних інститутах, а також у місцевих центрах підвищення кваліфікації державних службовців і посадових осіб місцевого самоврядування;

- заохочення систематичної самоосвіти в царині мовної й діловодної культури.

\section{Висновки}

Укладання комунікативної професіограми управлінця з поступовими змінами, уточненнями, а також пошук нових шляхів і форм здобуття необхідних умінь і навиків із питань формування мовленнєвої компетенції заслуговують на особливу увагу.

До механізмів удосконалення мовної і комунікативної компетенцій належить також розуміння сутнісних ознак мовної культури фахівців, теоретичних основ реалізації щодо української мови з урахуванням зарубіжного 
досвіду в цій сфері. Запровадження з 01.05.2017 Стандарту української мови для державних службовців згідно з постановою «Про організацію проведення атестації осіб, які претендують на вступ на державну службу, щодо вільного володіння державною мовою від 20.04.2017 № 301» є результатом узагальнення досвіду діяльності державної служби в Україні, демократичних країнах Європи та світу.

\section{ЛIТЕРАТУРА}

1. Бацевич Ф. С. Основи комунікативної лінгвістики: підручн. Київ: Вид. центр «Академія», 2004. 344 с. 2. Редін П. О. Культура мовлення державного службовця: навч. посіб. Харків: Вид-во ХарРІ НАДУ «Магістр», 2016. 200 с. 3. Українська мова: енциклопедія. Київ: Укр. енциклопедія, 2013. 4. Шевчук С. В., Клименко І. В. Укр. мова за професійним спрямуванням: підручн. 3-те вид., виправ. і доповнен. Київ: Алерта, 2013. $696 \mathrm{c}$.

\section{REFERENCES}

1. Batsevych, F. S. (2004). Osnovy komunikatyvnoi linhvistyky [Basics of communicative linguistics]. Kyiv: Akademiia [In Ukrainian]. 2. Redin, P. O. (2016). Kultura movlennia derzhavnoho sluzhbovtsia [Culture of speech of a civil servant]. Kharkiv: Mahistr [In Ukrainian]. 3. Ukrainska mova: entsyklopediia [Ukrainian language: Encyclopedia] (2013). Kyiv: Ukr. entsyklopediia [In Ukrainian]. 4. Shevchuk, S. V., Klymenko, I. V. (2013). Ukrainska mova za profesiinym spriamuvanniam [Ukrainian language in professional direction]. Kyiv: Alerta [In Ukrainian].

Загребельна Лариса Семенівна - кандидат філологічних наук, доцент, доцент кафедри української мови Харківського регіонального інституту державного управління Національної академії державного управління при Президентові України; просп. Московський, 75, Харків, 61000, Україна.

Тел.:+380 974548805

E-mail: lorazagreb@gmail.com https://orcid.org/000-000-0173-61-92-75

Zahrebelna Larysa Semenivna - PhD in Philology, Associate Professor, Ukrainian Language Department, Kharkiv Regional Institute of Public Administration of the National Academy for Public Administration under the President of Ukraine; Moskovskyi Av., 75, Kharkiv, 61000, Ukraine. 